\title{
6. UPPER JURASSIC-LOWEST CRETACEOUS LIMESTONES DREDGED FROM THE WESTERN GALICIA MARGIN ${ }^{1}$
}

\author{
Pierre-Alain Dupeuble, ${ }^{2}$ \\ Gilbert Boillot, ${ }^{3}$ and Denis Mougenot ${ }^{3}$
}

\begin{abstract}
Dredge samples of Upper Jurassic-lowest Cretaceous limestones were recovered from western Galicia margin. Limestones include benthic and/or planktonic assemblages, which were deposited in environments ranging from inner to outer shelf or upper slope.
\end{abstract}

\section{INTRODUCTION}

The morphology of the western Galicia margin is controlled by a complex network of Mesozoic and Cenozoic faults. Because of the thin sedimentary cover, fault scarps provide opportunities for sampling the basement rock and its overlying sediments (Upper Jurassic-lowest Cretaceous pre-rift sequence) by coring and dredging (Black et al., 1964; Funnel et al., 1969; Dupeuble et al., 1976; Boillot et al., 1979; Mougenot et al., 1985). These dredge and core samples supplement the drilling data from Deep Sea Drilling Project (DSDP) Site 398, which terminated in the Hauterivian syn-rift sediments (Sibuet, Ryan et al., 1979), and correspond to the limestone drilled at Site 639 during Ocean Drilling Program (ODP) Leg 103 (see Site 639 chapter, this volume).

This paper focuses on the stratigraphy and paleoenvironment of the Upper Jurassic-lowest Cretaceous carbonates, which built step scarps on the seafloor and were frequently sampled by dredging on the Galicia, Vigo, Porto and Vasco da Gama Seamounts (Fig. 1). The rest of the Mesozoic and Cenozoic rocks recovered in the dredges will not be discussed in this paper, as they were poorly sampled and consist of Upper Cretaceous and Cenozoic marl and shale with planktonic foraminiferal assemblages that were deposited in a deep-water environment (Boillot et al., 1979).

Dredge samples contain limestone of Kimmeridgian through Berriasian age. Because of the dredging techniques, a single dredge haul sometimes included samples from different stratigraphic levels and/or paleoenvironments (Table 1). We, therefore, classified the carbonates recovered in the dredge according to their microfacies rather than according to stratigraphic succession. These carbonates can be divided into two main types: (1) limestone containing a dominantly benthic assemblage, and (2) limestone having a dominantly planktonic assemblage. The latter type of limestone is rare.

\section{LIMESTONE WITH BENTHIC ASSEMBLAGES}

Limestone having skeletal remains of a dominantly benthic origin that were probably deposited in situ are termed limestone with benthic assemblages.

\footnotetext{
${ }^{1}$ Contribution No. 354 of the Groupe d'Etude de la Marge Continentale, Université Pierre et Marie Curie of Paris, and CNRS.

2 Laboratoire de Géologie, Université de Rouen, Faculté des Sciences, 76130 Mont-St.-Aignan (France).

${ }^{3}$ Laboratoire de Géodynamique Sous-Marine du CEROV, B.P. 48, 06230 Villefranche-Sur-Mer (France).
}

\section{Clypeina jurassica Limestone}

Clypeina is generally preserved in micritic limestone (Pl. 1, Fig. 1), though it also occurs in fine-grained pelloidal limestone associated with other algae such as Taumatoporella parvovesiculifera (Pl. 1, Fig.2). This facies indicates a shallow-water and low-energy depositional environment. These limestones were probably deposited during Kimmeridgian through Portlandian times because Clypeina jurassica is not found in the Cretaceous of Algarve (south Portugal) (Ramalho, 1971; Durand-Delga and Rey, 1982). C. jurassica is, however, observed in the PortlandianBerriasian limestone of the western Pyrenees (Peybernes, 1976). According to Bassoulet et al. (1978), this algae existed from the Kimmeridgian to the Berriasian, and culminated during late Kimmeridgian and Portlandian times.

\section{Bacinella irregularis Limestone}

Bacinella irregularis is preserved in many well-developed limestone nodules and is commonly associated with Lithocodium aggregatum. Several authors (Bouroullec and Deloffre, 1968; Ramalho, 1971) have emphasized the affinities between these two species, both of which encrust and, in some places, are the dominant or only bioclastic component of the limestone. This sedimentary facies generally indicates a high- to moderate-energy depositional environment. However, Lithocodium aggregatum appearing alone suggests a more protected environment. The two algae are also associated in some samples with Clypeina jurassica (PI. 1, Fig. 3) or with less common Cayeuxia piae ( $\mathrm{Pl}$. 1, Fig. 4). In those samples, an even more protected environment seems to be indicated. According to Ramalho (1971), $B$. irregularis and L. aggregatum co-occurred during Portlandian-Berriasian time.

\section{Oncolithic Limestone}

Oncolithic limestone is similar to that deposited in Algarve from Oxfordian to Portlandian time, mainly from the late Kimmeridgian to Portlandian (Ramalho, 1971; Durand-Delga and Rey, 1982), and is of Tethyan affinity. Many of the oncoliths are built around a Nodophthalmidium clast, though they occur in some samples around a calpionellid lorica. Oncolithic limestones are generally deposited in moderate- to low-energy environments, probably on a more external part of the shelf than are the algae limestones described previously.

\section{Foraminiferal Limestone}

Most foraminiferal limestone samples recovered in the dredge are compositionally pelletoidal bioclastic wackestones to packstones (Pl. 2, Figs. 2 and 4), deposited in a low- to moderate-en- 


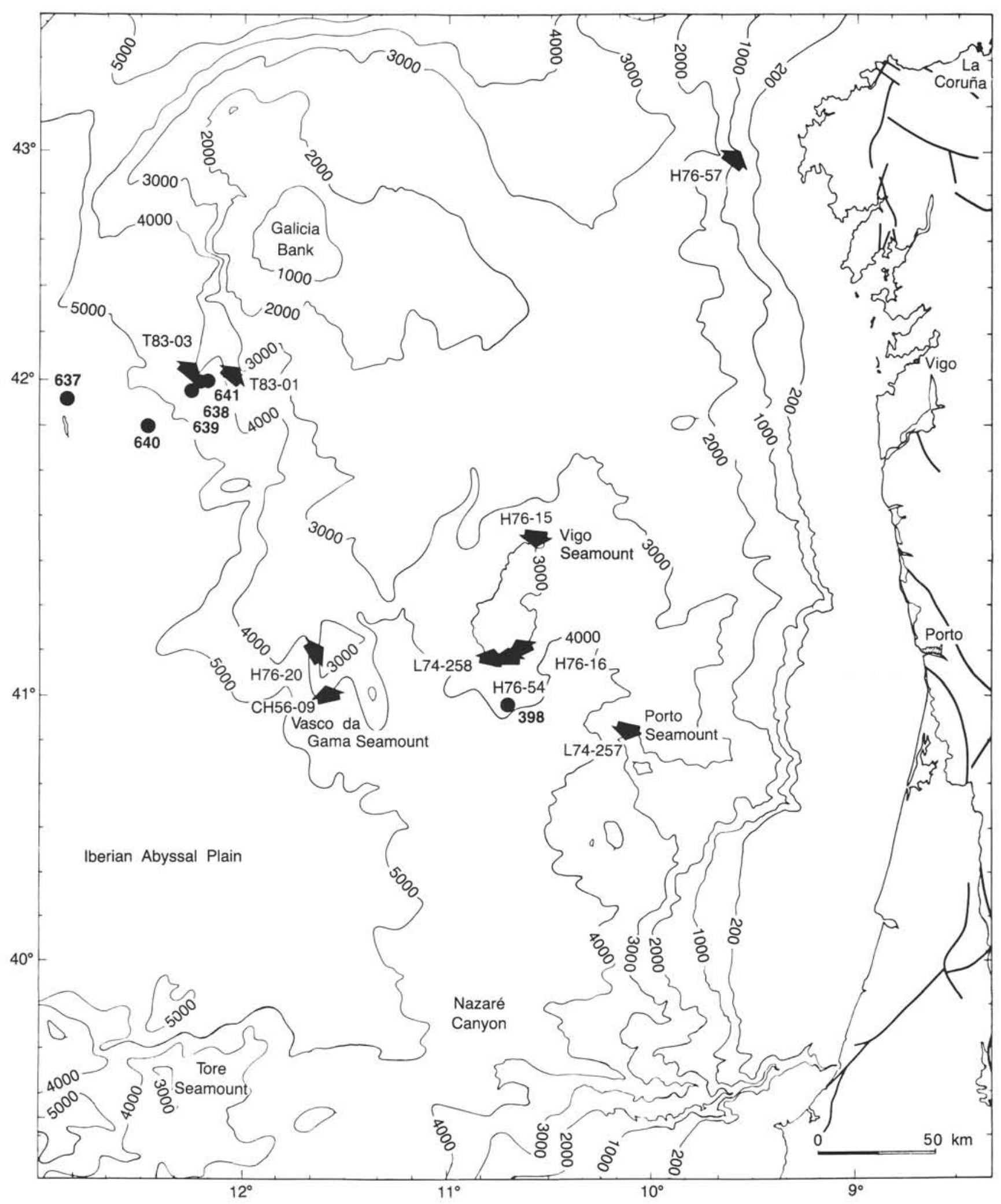

Figure 1. Location of dredges (black arrows) where the Upper Jurassic-lowest Cretaceous carbonate platform was sampled. Locations of ODP Leg 103 Sites 637-641 and DSDP Site 398 are also shown (black dots). Bathymetric contours in meters. 
Table 1. Classification of limestone samples recovered in dredge hauls. See Figure 1 for dredge locations.

\begin{tabular}{|c|c|c|c|c|c|c|c|c|c|c|}
\hline & 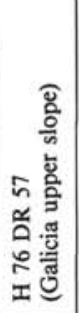 & 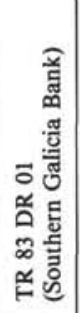 & 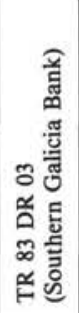 & 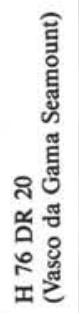 & 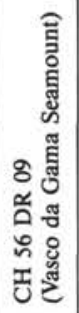 & 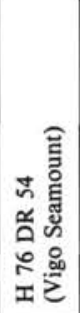 & 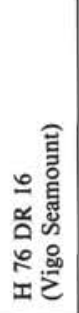 & 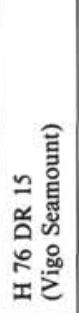 & 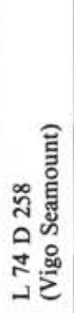 & 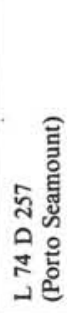 \\
\hline $\begin{array}{l}\text { Limestone with } \\
\text { Clypeina jurassica } \\
\text { Limestone with } \\
\text { Bacinella irregularis } \\
\text { Oncolithic limestone } \\
\text { Foraminiferal limestone } \\
\text { Limestone with } \\
\text { calpionellids }\end{array}$ & $\mathrm{X}$ & $\begin{array}{l}X \\
x \\
X\end{array}$ & $\mathrm{X}$ & $\begin{array}{l}X \\
X\end{array}$ & $X$ & $\begin{array}{l}x \\
x\end{array}$ & $\begin{array}{l}x \\
x \\
x\end{array}$ & $\begin{array}{l}x \\
x \\
x \\
x\end{array}$ & $\begin{array}{l}x \\
x\end{array}$ & $\begin{array}{l}X \\
X \\
X\end{array}$ \\
\hline
\end{tabular}

ergy environment. In some samples, they resemble the sponge facies described on the Morocco margin by Steiger and Jansa (1984) (Pl. 2, Fig. 3). Some of the foraminiferal limestones have a small amount of dolomite but lack a terrigenous component; similar limestone was interpreted by Peybernes (1976) as having been deposited in a very shallow-water environment.

Many samples contain relatively common foraminifers characteristic of the Jurassic/Cretaceous boundary, such as Pseudocyclammina lituus, Conicospirillina basiliensis, Trocholina elongata, T. alpina, and Nautiloculina oolitica. In addition, limestones with Anchispirocyclina lusitanica were sampled southwest of Galicia Bank (Mougenot et al., 1985) near Site 639 (Pl. 3, Figs. 1 and 2). According to Jansa et al. (1980) and to DurandDelga and Rey (1982), the top of the Anchispirocyclina layers coincides with the upper limit of the Jurassic. In Algarve (DurandDelga and Rey, 1982), limestone with abundant Trocholina overlies the Anchispirocyclina level. On the basis of facies similarities, we assigned a probable earliest Cretaceous age to samples having numerous Trocholina (Pl. 2, Fig. 1).

\section{LIMESTONE WITH PLANKTONIC ASSEMBLAGES}

Limestone with planktonic assemblages was observed in only three samples:

1. A poorly cemented microbreccia dredged on the Vasco da Gama Seamount (Fig. 1). The micritic clasts contain a calpionellid assemblage composed mainly of Calpionella alpina, Tintinopsella gr. carpathica, and Crassicolaria gr. intermedia (Pl. 3, Fig. 3). The assemblage is late Tithonian in age.

2. A fine-grained limestone with micritic intraclasts sampled on the Vigo Seamount. The assemblage consists of Calpionella alpina, rare Tintinopsella carpathica, and Crassicolaria parvula. This assemblage was probably living during the Jurassic/ Cretaceous transition, possibly during the early Berriasian.

3. A micritic limestone, mixed with bioclastic packstone, including a benthic assemblage, sampled southwest of Galicia Bank. The calpionellid assemblage is the same as that described in the sample from the Vigo Seamount. Nevertheless, this last example suggests coexistence of benthic and planktonic assemblages in Tithonian-Berriasian limestone, probably on the external shelf. Such a relationship is not rare and has also been observed on the Morocco margin (Jaffrezo et al., 1985) and on the north Spanish margin (Malod and Boillot, 1980), as well as on the eastern Canadian margin (Jansa et al., 1980).

Calpionellid assemblages occur on both the eastern and western North Atlantic margins (Boillot et al., 1971; Durand-Delga,
1973; Jansa et al., 1980; Jansa, 1981). Their occurrence implies an open sea and an active paleocirculation pattern between the Tethyan and Atlantic Oceans. The micritic limestone commonly associated with the calpionellids indicates a low-energy depositional environment, possibly located on the upper slope, more probably on the outer shelf.

\section{CONCLUSIONS}

On the western Galicia margin, the oldest dated Mesozoic sediments sampled by dredging are Tithonian limestones. The samples consist of platform carbonates, which are partly dolomitized and were deposited in a variety of paleoenvironments on a broad shelf. Micritic limestone with calpionellids were probably deposited on an outer shelf or on the upper slope in an open sea, which mixed easily with the Tethys and the central North Atlantic Ocean. In contrast, foraminiferal and algae limestones were probably deposited on the inner shelf. The lack of detrital component suggests that the adjacent continent was flat and protected from uplift and erosion, as expected during the pre-rift stage of the margin evolution.

\section{ACKNOWLEDGMENTS}

We thank M. Durand-Delga for help determining calpionellids and M. Moullade, A. Meyer, and an anonymous reviewer for useful comments on the first draft of this paper.

\section{REFERENCES}

Bassoullet, J. P., Bernier, P., Conrad, M. A., Deloffre, R., and Jaffrezo, M., 1978. Les Algues Dasycladales du Jurassique et du Crétacé. Geobios Mémoire, 2:330.

Black, M., Hill, M., Laughton, A. S., and Matthews, D. H., 1964. Three non-magnetic seamounts off the Iberian coast. Geol. Soc. London, Q. J., 120:477-517.

Boillot, G., Dupeuble, P. A., Durand-Delga, M., and Dozouville, L., 1971. Age minimal de l'Atlantique Nord d'après la découverte de calcaire tithonique à Calpionelles dans le golfe de Gascogne. Acad. Sci. Paris, C. R., 273:671-674.

Boillot, G., Auxietre, J. L., Dunand, J. P., Dupeuble, P. A., and Mauffret A., 1979. The northwestern Iberian margin: a Cretaceous passive margin deformed during Eocene. M. Ewing Series No. 3: Washington (Am. Geophys. Union), 138-153.

Bouroullec, J., and Deloffre, R., 1968. Les algues du Néocomien d'Aquitaine. Bull. Cent. Rech. Pau, S. N. P. A., 2(2):213-261.

Dupeuble, P. A., Rehault, J. P., Auxietre, J. L., Dunand, J. P., and Pastouret, L., 1976. Résultats de dragages et essai de stratigraphie des bancs de Galice et des montagnes de Porto et de Vigo. Mar. Geol., 22:M37-M49. 
Durand-Delga, M., 1973. Les Calpionelles du golfe de Gascogne, témoins de l'ouverture de l'Atlantique Nord. Bull. Soc. Géol. Fr., (7) XV, 1:22-24.

Durand-Delga, M., and Rey, J., 1982. Découverte de Calpionelles dans le Jurassique terminal et le Crétacé basal de l'Algarve (Portugal). Acad. Sci. Paris, C. R., 295, II, 2:232-237.

Funnel, B. M., Friend, J. K., and Ramsey, A. T. S., 1969. Upper Maestrichtian planktonic foraminifera from Galicia Bank, west of Spain. Paleontology, 12(1):19-42.

Jaffrezo, M., Medina, F., and Chorowicz, J., 1985. Données microbiostratigraphiques sur le Jurassique supérieur du bassin de l'Ouest marocain. Comparaisons avec les résultats du Leg 79 DSDP et de la campagne CYAMAZ (1982). Bull. Soc. Géol. Fr., 6:875-884.

Jansa, L. F., 1981. Mesozoic carbonate platforms and banks of the eastern North American margin. Mar. Geol., 44:97-117.

Jansa, L. F., Remane, J., and Ascoli, P., 1980. Calpionellid and foraminiferal-ostracod biostratigraphy at the Jurassic-Cretaceous boundary, offshore eastern Canada. Riv. Ital. Paleont., 86(1):67-126.
Malod, J. A., and Boillot, G., 1980. Campagne Cyadanois. Résultats des Campagnes á la Mer, 20: Paris (CNEXO).

Mougenot, D., Capdevilla, R., Palain, C., Dupeuble, P. A., and Mauffret, A., 1985. Nouvelles données sur les sédiments anterift et le socle de la marge continentale de Galice. Acad. Sci. Paris, C. R., 301, II, 5:323-328.

Peybernes, B., 1976. Le Jurassique et le Crétacé inférieur des Pyrénées franco-espagnoles entre la Garonne et la Méditerranée [Thèse Doct. Sc. Nat.]. Toulouse.

Ramalho, M. M., 1971. Contribution à l'étude micropaléontologique et stratigraphique du Jurassique supérieur et du Crétacé inférieur des environs de Lisbonne (Portugal). Serv. Geol. Portugal, Mem. 19 (Nova serie).

Sibuet, J. C., Ryan, W. B. F., et al, 1979. Init. Repts. DSDP, 47(2): Washington (U.S. Govt. Printing Office).

Steiger, T., and Jansa, L. F., 1984. Jurassic limestones of the seaward edge of the Mazagan carbonate platform, northwest African continental margin, Morocco. In Hinz, K., Winterer, E. L., et al., Init. Repts. DSDP, 79: Washington (U.S. Govt. Printing Office), 449-477. 


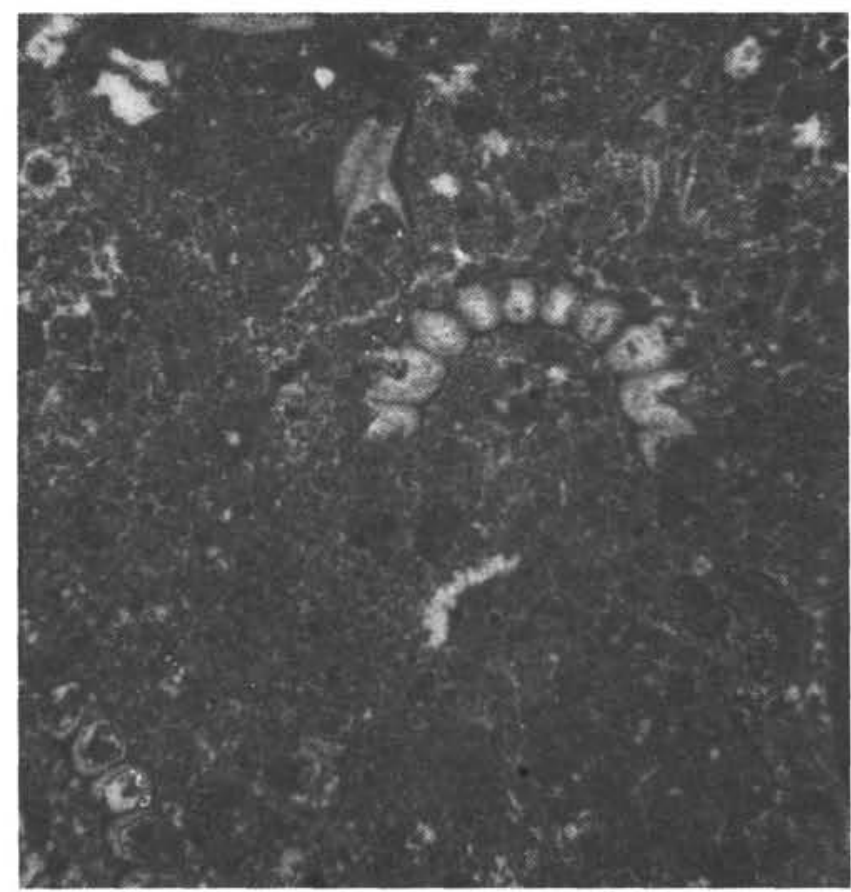

1

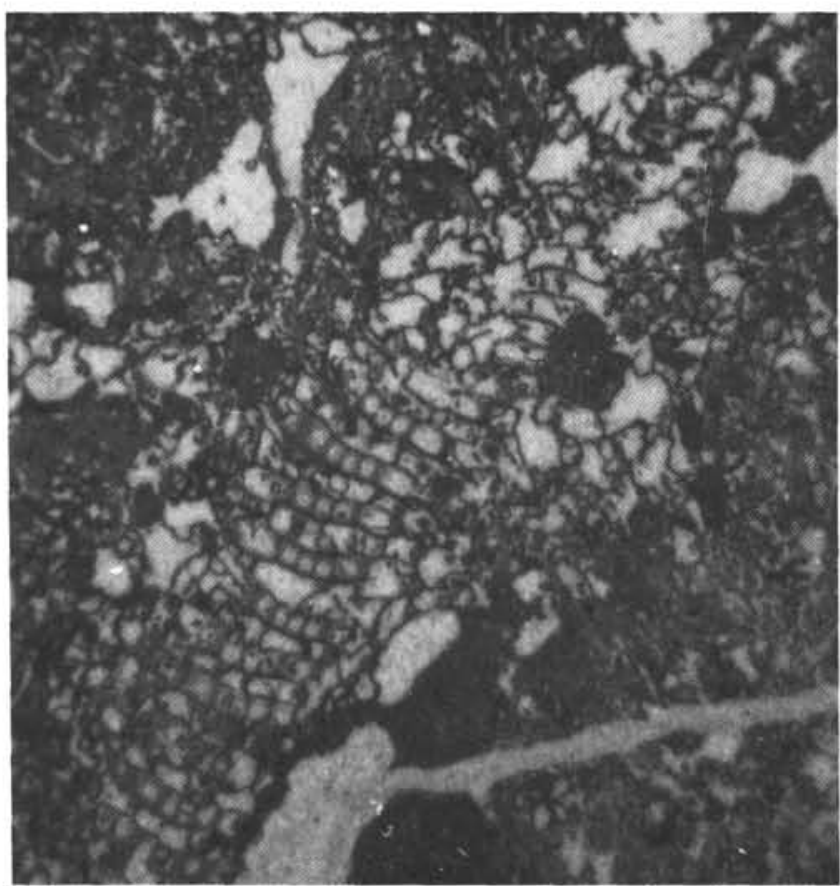

3

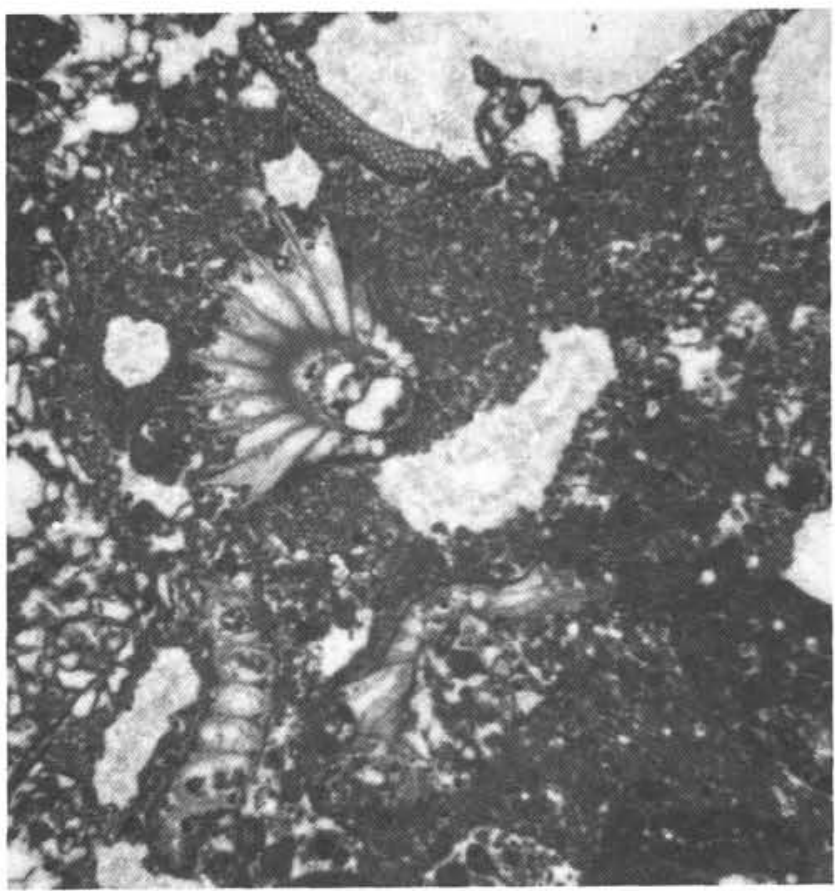

2

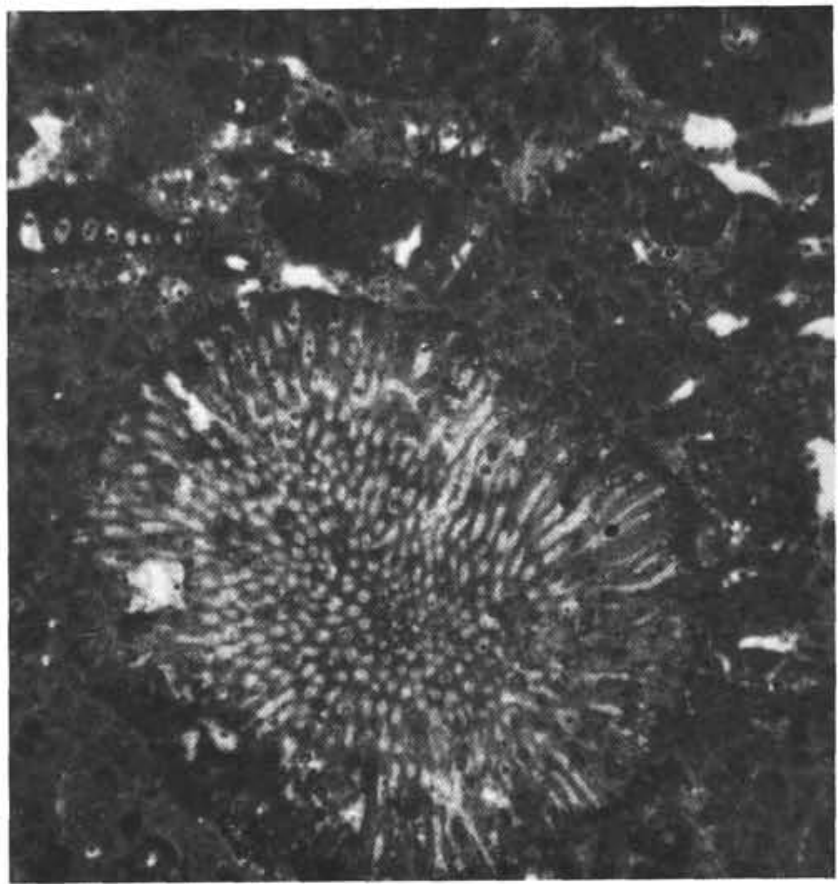

4

Plate 1. 1. Wackestone with Clypeina jurassica. Sample H76 DR 15B $(\times 20)$. 2. Pelloidal wackestone with Clypeina jurassica, Taumatoporella parvovesiculifera, and some Bacinella irregularis remains. Sample H76 DR 15D $(\times 20)$. 3. Pelloidal packstone with fertile whorls of Clypeina jurassica encrusted with Bacinella irregularis. Sample H76 DR 15F $(\times 12)$. 4. Pelloidal wackestone with Cayeuxia piae. Sample H76 DR 16D $(\times 25)$. 


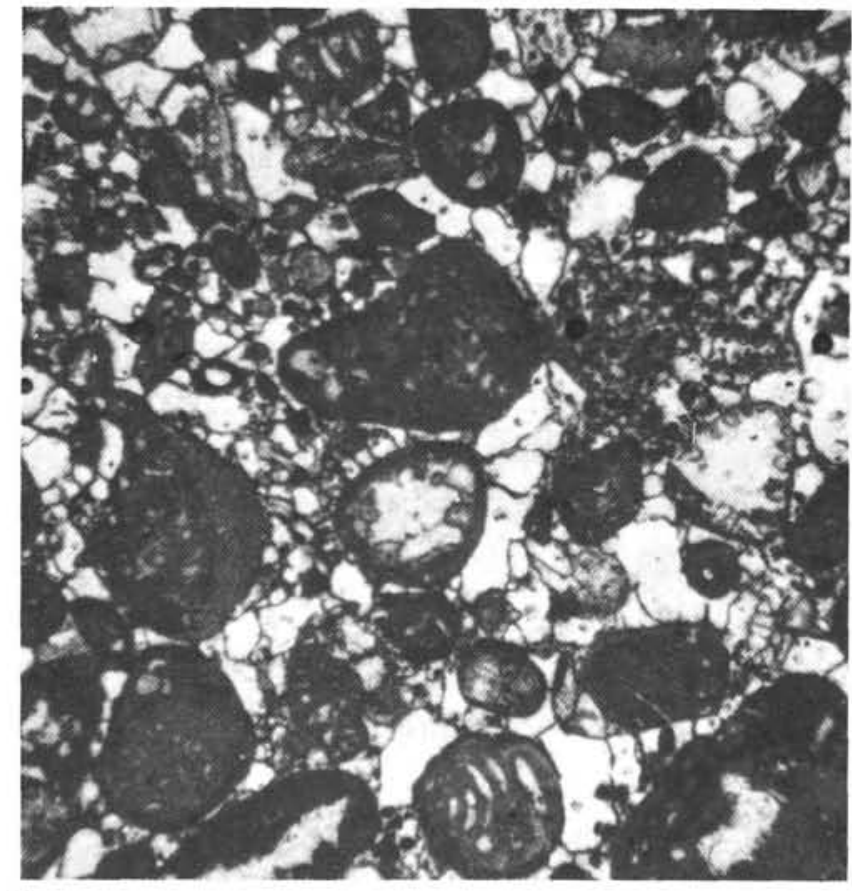

1

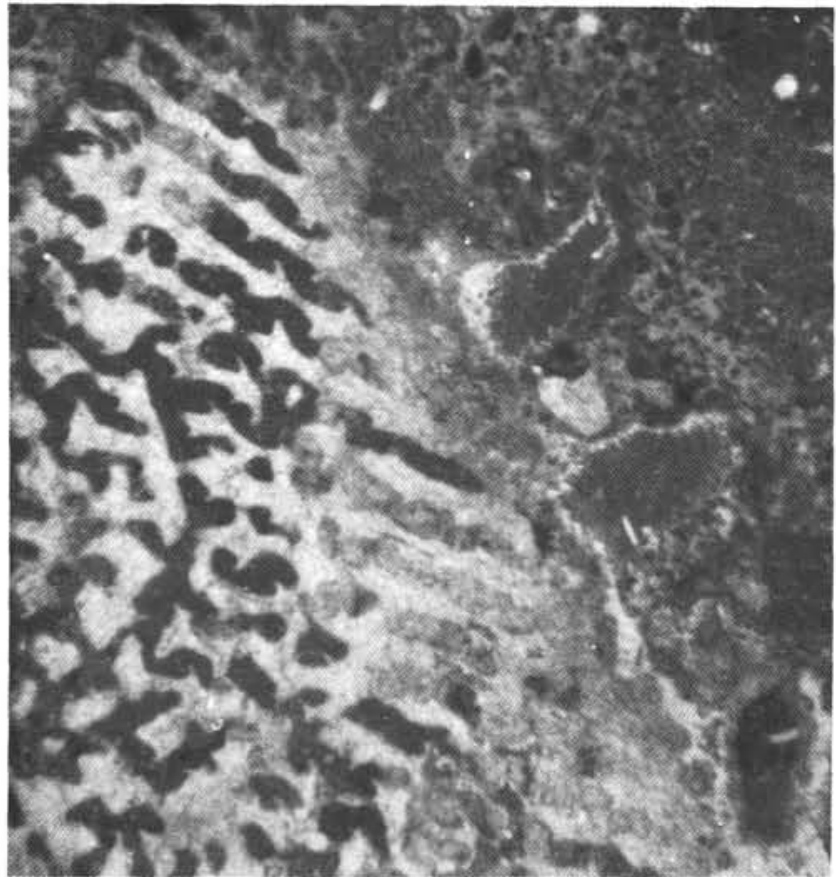

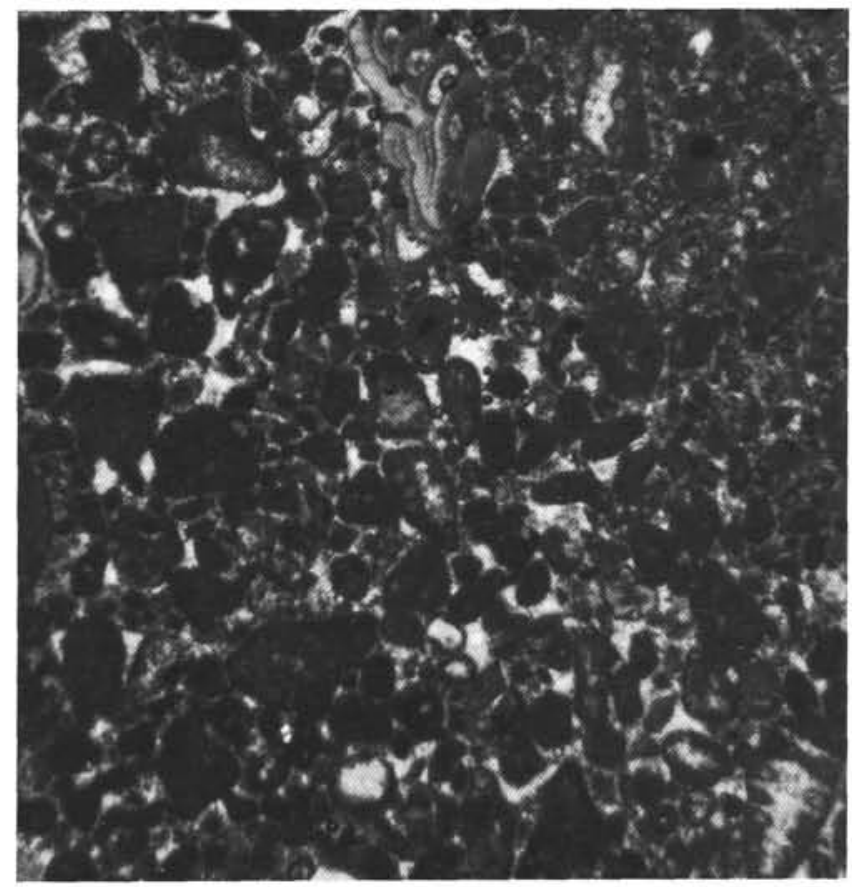

2

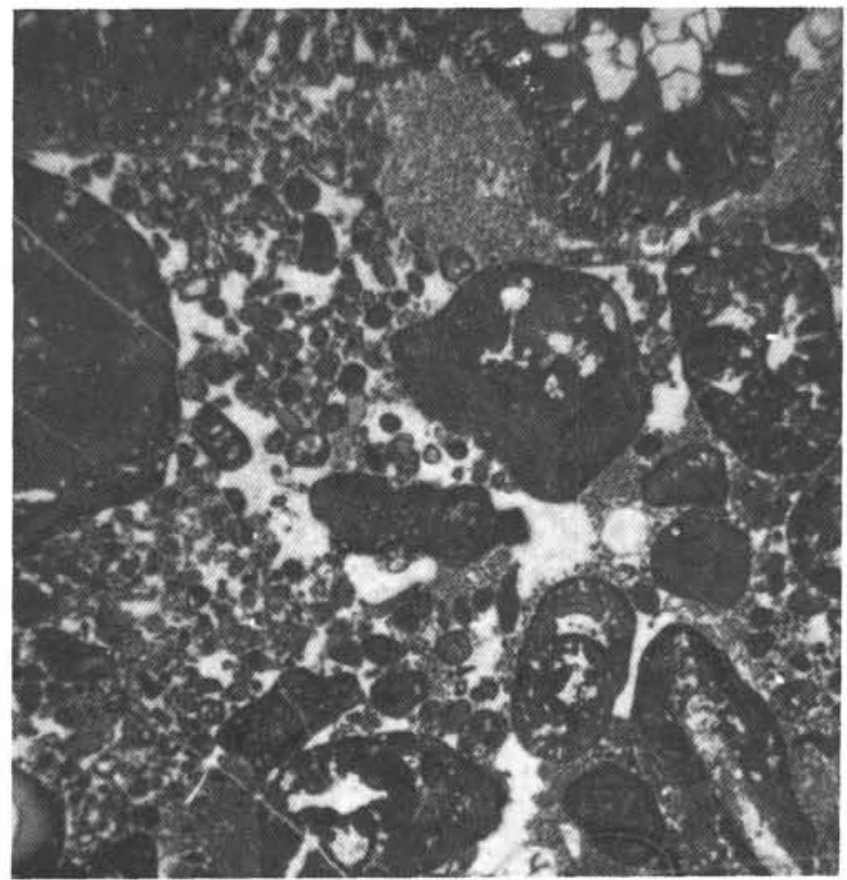

Plate 2. 1. Bioclastic grainstone with Trocholina alpina, Conicospirillina basiliensis, and oncoids encrusted with Bacinella irregularis. Sample H76 DR 16C $(\times 15)$. 2. Pelloidal bioclastic packstone with Trocholina elongata and Conicospirillina basiliensis. Sample H76 DR 57F $(\times 20)$. 3. Coral remains in pelloidal bioclastic wackestone. Sample TR 83 DR 01. a $1(\times 15)$. 4. Pelloidal bioclastic packstone with oncoids, Lithocodium aggregatum, and Pseudocyclammina. Sample L74 D $257.2(\times 15)$. 


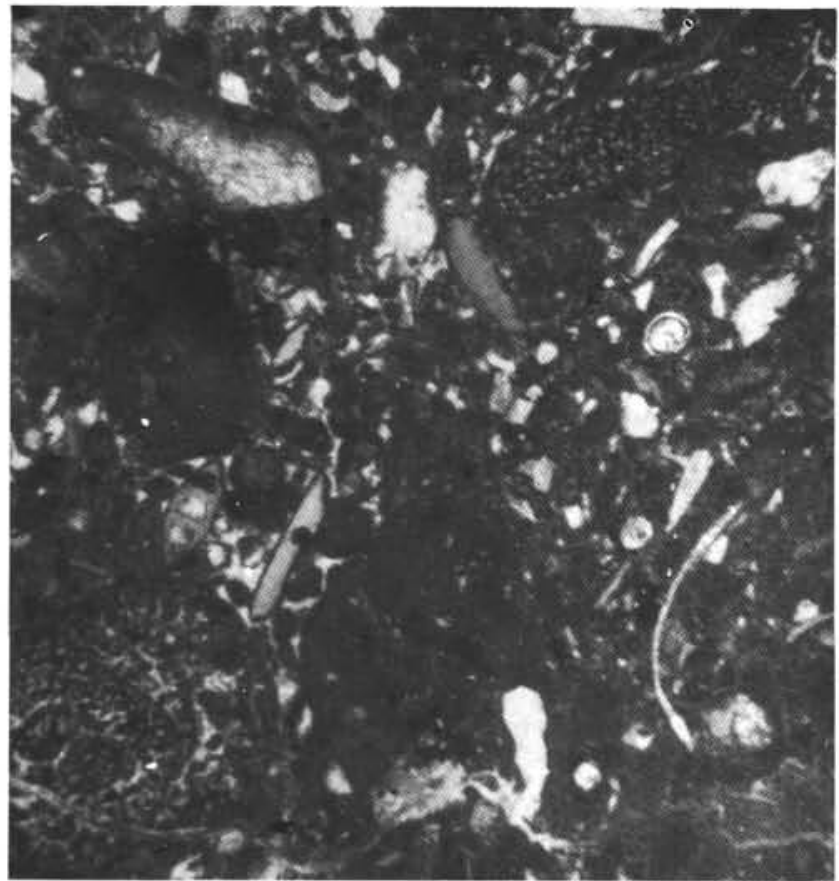

1

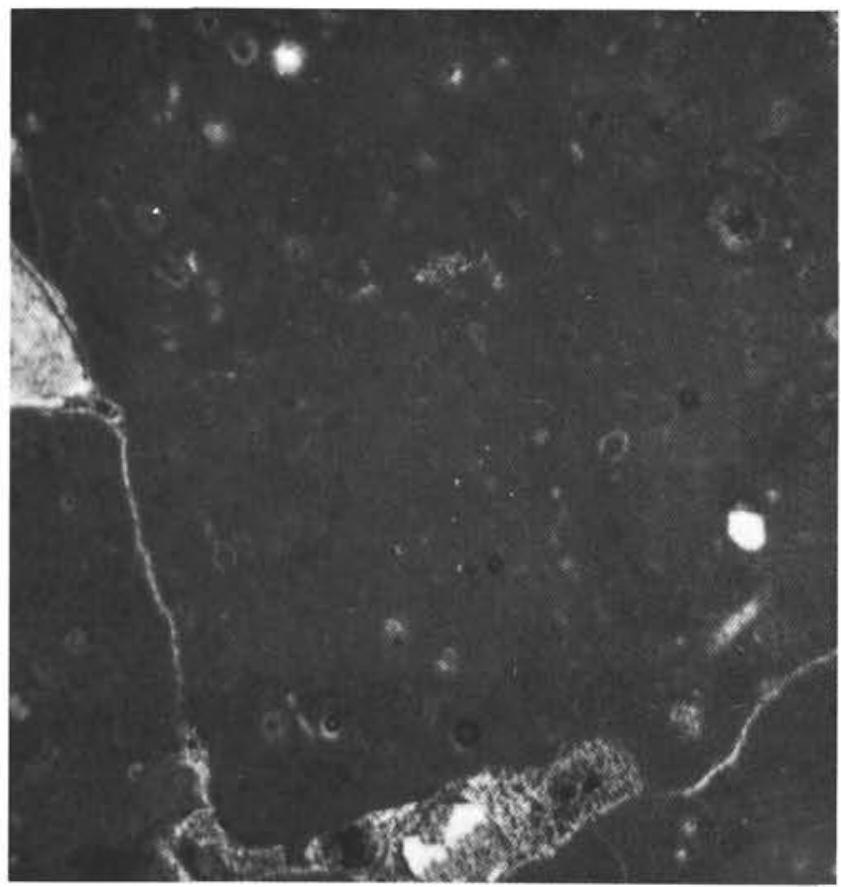

3

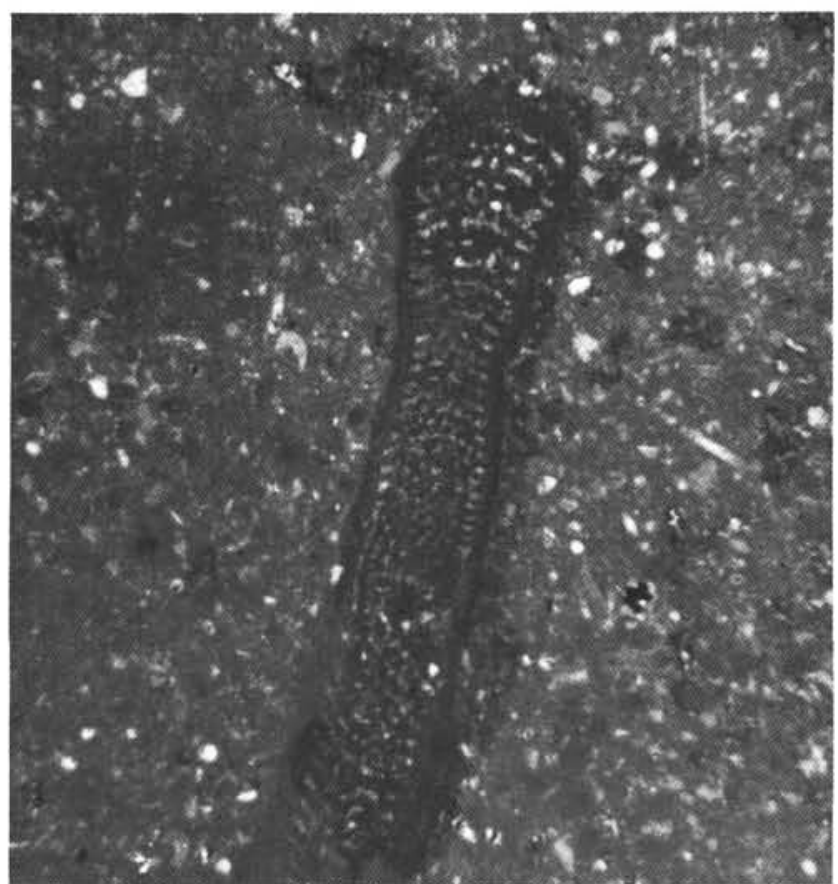

2

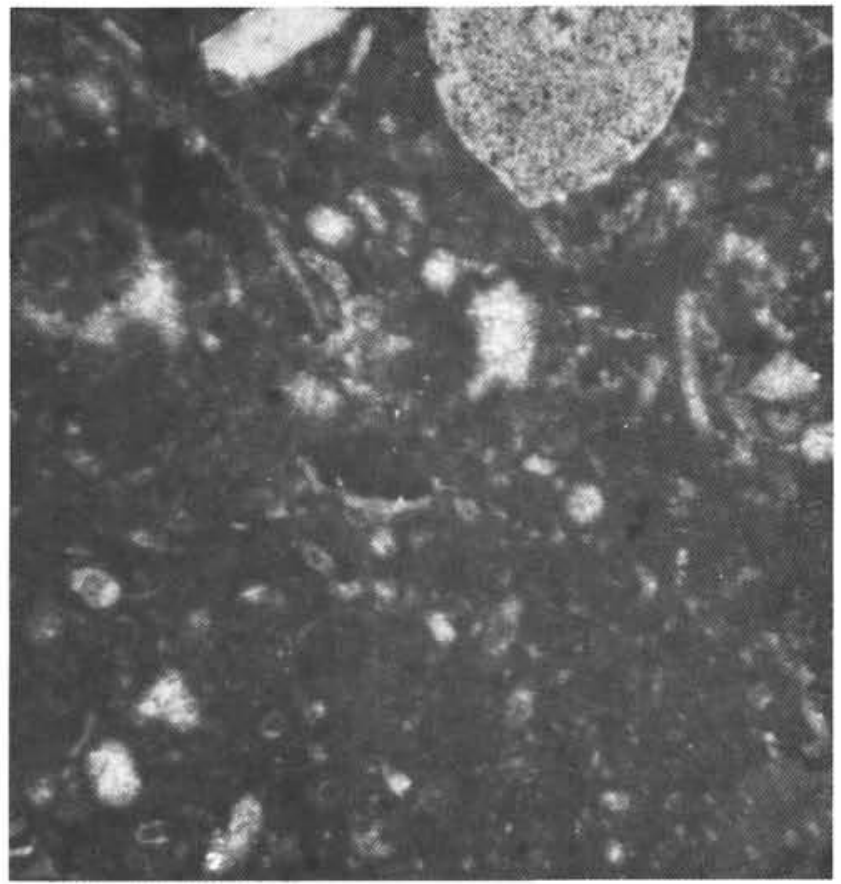

4

Plate 3. 1. Bioclastic packstone with Anchispirocyclina lusitanica, Lenticulina, gastropod and pelecypod remains, and oncoids. Sample TR 83 DR $01 \mathrm{~B} 2(\times 12)$. 2. Wackestone with Anchispirocyclina lusitanica. Sample TR 83 DR $01 \mathrm{e}(\times 25)$. 3. Mudstone with calpionellids (Calpionella alpina and Crassicolaria intermedia). Sample CH 56 DR $09(\times 50)$. 4. Bioclastic wackestone with crinoid, various small remains, and calpionellids. Sample TR 83 DR $01 \mathrm{C}(\times 50)$. 